NBER WORKING PAPER SERIES

DEVELOPING COUNTRY BORROWING AND DOMESTIC WEALTH

Mark Gertler

Kenneth Rogoff

Working Paper No. 2887

NATIONAL BUREAU OF ECONOMIC RESEARCH

1050 Massachusetts Avenue

Cambridge, MA 02138

March 1989

We are grateful to the National Science Foundation, the Sloan Foundation, and the Bradley Foundation for financial support. This paper is part of NBER's research program in International Studies. Any opinions expressed are those of the authors not those of the National Bureau of Economic Research. 
NBER Working Paper \#2887

March 1989

\section{DEVELOPING COUNTRY BORROWING AND DOMESTIC WEALTH}

\section{ABSTRACT}

We show that across developing countries, external debt to private creditors rises more than proportionately with income. We then develop a simple theoretical model consistent with this phenomenon and also consistent with the well-documented relationship between capital market development and growth. Our framework stresses information asymmetries at the level of individual borrowers as the source of frictions in world capital markets. Because of moral hazard problems, marginal products of capital and borrowing-lending spreads are higher in poorer countries. In a two-country version of the model, we demonstrate the possibllity of a "siphoning effect" which exacerbates the costs of transfers. Also because of the siphoning effect, increased wealth in the rich country can stunt investment in the poor country.

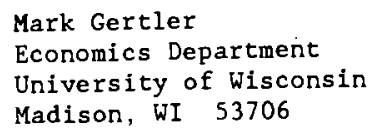

\author{
Kenneth Rogoff \\ Economics Department \\ University of Wisconsin \\ Madison, WI 53706
}




\section{Introduction}

The standard neoclassical model of trade and growth predlcts that rich-country savers w11l lend to Investors In hlgh-marglnal-product-of-capital poor countries. After the deregulation of International capital markets in the 1960s, the 1970s Indeed witnessed a broad expansion of lending from industrlallzed countrles to the developing world. However, for certaln features of the data, the standard wodel does not seem to provide the simplest explanation. For example, during the 1970s "wlddle Income" developing countrles were able to borrow more per cap1ta than poorer countries. Using data from 1980 for a cross-section of seventy countrles, we show that for each percentage polnt Increase In per capita Income, per capita external debt to private creditors tends to rise significantly more than one percent. Moreover, this relation between external debt and national Income tends to hold across countries withln the sane reglon (Afrlca, Asia, and Latin America).

Our alm is to provide a natural explanation of this evidence whlch is also consistent with the well-documented positive relationshlp between capital market development and growth [Goldsmlth (1969) and Mckinnon (1973)]. The framework here stresses asymmetric information at the level of Individual borrowers as a source of (endogenously-derived) frictlons in world capltal markets. ${ }^{1}$ A positive relation between external borrowing and the state of development can emerge because in wealthler countrles firms are better capltallzed. Informatlonal problens consequently have less impact, resulting

${ }^{1}$ Our analysis draws on recent developments in the closed-economy literature on interactions between the real and flnanclal sectors; see Gertler (1988) for a survey. To abstract from soverelgn risk, we assume that there is a supranational legal authority, capable of enforcing contracts across borders. Hence our analysis is really as much a model of capltal flows between Manhattan and the Bronx as between Japan and Indla. 
In a lower cost difference between Internal (to a firm) finance and external finance.

Thus even in a world of perfectly integrated capltal markets, in which riskless rates are equalized, marginal products of capltal can differ across nations. An important emplrical implication is that the spread between borrowing and lending rates should be larger in poorer countrles, which most development economists take as a styllzed fact.

Section II of the paper presents some simple correlations between national income and borrowing. A small-country model is presented in section III and a two-country general equllibrium version is given in section IV. The two-country model ylelds an interesting new perspective on the classic transfer problem: The cost to a country of repaying a debt may exceed the face value of the debt, since the decline in wealth exacerbates the information-induced loan market inefficlencies. Also, a rise in capital market efficlency in the rich country can lead to a "slphoning" of investment funds from the poor country. In the conclusions, we discuss some possible alternative explanations for the positive relation between capital inflows and domestic wealth.

\section{External Debt and GNP for Developing Countries}

In Table 1, we present 1980 data on Income and external borrowing for seventy developing countries, listed in order of GNP per caplta: The second column lists external debts owed to private lenders; the third column also Includes debts owed to other governments and to multilateral credit agencies (e.g., the International Monetary Fund and the World Bank). A casual comparison of column one with elther column two or three indicates a strong correlation between GNP and external borrowing. Table 2 contains two sets of 
TABLE ?

Measures of External Borrowing Versus GNP: 1980

DOLLARS PER CAPITA

GNP

Bthlopia $\quad 107$

Uganda 131

Nepal 142

Bangladesh 144

Chad 162

Burme . 171

Malawi 190

Burund 1222

Rwanda 226

Mal1 231

Burkina Baso 234

Indla 256

Sri Lanka 271

Tanzania 276

Pakistan 283

Ha1t1 289

Sierra Leone 321

Benin 331

Cen. Afr. Rep. 343

Sudan 368

Somalla 361

Madagascar 370

Zaire 380

Ghana 384

Kenya 412

Mauritania $\quad 412$

Togo 435

Niger 471

Lesotho 481

Senegal

Yemen A.R.

Indoneria

Egypt

Bolivia

Liberia

zambia

Honduras

Tha 1 land

Philippines

El Salvador

Cameroon

Papua New Gui.

Morocco

Botswene

Congo
Bxternal Debt

to Private Lenders

16

0

3

14

9

51

5

6

8

9

3

25

46

16

7

51

69

30

78

13

68

71

24

117

122

208

111

14

106

17

78

149

263

131

226

201

124

284

87

150

169

240

11

663
Total

External Debt

21

56

15

45

49

45

136

40

37

101

54

29

125

138

120

60

131

120

82

268

191

144

183

114

210

511

408

163

53

225

165

143

470

482

383

558

400

178

360

202

296

243

483

190

1096 


$\begin{array}{lrrr}\text { Dominican Rep. } & 1096 & 212 & 368 \\ \text { Jordan } & 1122 & 259 & 601 \\ \text { Guatemala } & 1128 & 91 & 168 \\ \text { Peru } & 1139 & 373 & 578 \\ \text { Jamaica } & 1157 & 318 & 885 \\ \text { Cote D'Ivoire } & 1206 & 703 \\ \text { Nigeria } & 1236 & 57 & 110 \\ \text { Turkey } & 1256 & 190 & 428 \\ \text { Columbia } & 1285 & 176 & 268 \\ \text { Tunisia } & 1332 & 243 & 554 \\ \text { Ecuador } & 1373 & 577 & 739 \\ \text { Paraguay } & 1467 & 174 & 304 \\ \text { Syria } & 1518 & 111 & 315 \\ \text { Korea } & 1584 & 414 & 773 \\ \text { Panama } & 1754 & 1235 & 1565 \\ \text { Brazil } & 1912 & 525 & 582 \\ \text { Argentina } & 1987 & 894 & 962 \\ \text { Cogta Rica } & 2044 & 846 & 1216 \\ \text { Algeria } & 2203 & 851 & 1001 \\ \text { Chile } & 2391 & 951 & 1084 \\ \text { Portugal } & 2431 & 750 & 982 \\ \text { Mexico } & 2726 & 763 & 828 \\ \text { Uruguay } & 3448 & 575 & 1462 \\ \text { Gabon } & 3584 & 1108 & 1963 \\ \text { Venezuala } & 3961 & 1929 & \end{array}$

Sources: World Bank, World Debt Tables: External Debt of Developing Countries, Vol. II, 1988-89 ed., and International Monetary Fund, International Financial statistics.

Notes: Total external debt includes public and publicly guaranteed long-term debt, private non-guaranteed long-term debt, IMF credit, and short-term debt. External debt to private lenders includes long-term public and publicly guaranteed debt to private creditors, long-term private non-guaranteed debt, and short-term debt. All of the World Bank's list of developing countries are included above, except those with 1986 populations under one million and/Or GNP per capita over $\$ 3,000$. Commist countries are also excluded; Bhutan, Lebanon; Guinea, zimbawe Malaysia are excluded due to insufficient data. 


\section{TABLE 2}

\section{OLS Reqressions of Debt/Capita on GNP/Capita for Developine Conritries: 1980}

\section{log Total Extemal \\ Debt per Capita}

All countries

Sub-Saharan

Africa

Latin America

and Caribbean

Asia

\section{Constant}

$-1.29$

$-1.40$

$-.78$

$-236$ $\log$ GNP
per Capite

1.05

1.08

(.16)

.97

120

(.19)
\# Observations

$R^{2}$

68

.73

30

.60

19

.56

10

.83

\begin{tabular}{|c|c|c|c|c|}
\hline $\begin{array}{l}\text { log External Debt } \\
\text { to Private Lenders } \\
\text { per Capita }\end{array}$ & Constant & $\begin{array}{l}\log \text { GNP } \\
\text { per Capita }\end{array}$ & \# Observations & $R^{2}$ \\
\hline All Countries & -5.84 & $\begin{array}{l}1.60 \\
(.12)\end{array}$ & 68 & .73 \\
\hline $\begin{array}{l}\text { Sub-Saharan } \\
\text { Africa }\end{array}$ & -5.20 & $\begin{array}{l}1.51 \\
(.25)\end{array}$ & 30 & .55 \\
\hline $\begin{array}{l}\text { Latin America } \\
\text { and Caribbean }\end{array}$ & -5.16 & $\begin{array}{l}1.51 \\
(.29)\end{array}$ & 19 & .62 \\
\hline Asia & -9.77 & $\frac{222}{(30)}$ & 10 & .87 \\
\hline
\end{tabular}

Africa: Benin, Botwana, Burkina Faso, Burundi, Cameroon, Central African Republic, Chad, Congo, Cote D'Ivoire, Ethiopia, Ghane, Kenya, Lesotho, Liberin, Madagascar, Malawi, Mali, Mauritania, Niger, Nigeria, Rwanda, Senegal, Sierra Leone, Somalia, Tanzania, Togo, Uganda, Zaire, Zambia.

Latin America and the Caribbean: Argentina, Bolivia, Brazil, Chile, Columbia, Costa Rica, Dominican Republic, Ecuador, El Salvador, Guatemala, Haiti, Honduras, Jamaica, Mexico, Panama, Paraguay, Peru, Uruguay, Venezuela.

Asia: Bangladesh, Burma, India, Indonesia, Korea, Pakistan, Papua New Guinea, Philippines, Sri Lanka, Thailand.

Ocher: Algeria, Egypt, Jordan, Morocco, Portugal, Syria, Tunisia, Turkey, Yemen Arab Republic. 
regressions, both using the log of GNP per capita as the explanatory variable. In the first, the dependent variable is the log of total external debt per capita. Over the entire sample ${ }^{2}$, the coefficient on GNP was 1.05 , with a standard error of .08. Separate regressions for Asia, Africa, and Latin America yield similar results.

One problem with using total external debt to measure country borrowing is that the component consisting of official (public) debt is probably best viewed as foreign ald. Whereas most official debt is senior in principle, it is junlor to private debt in practice. Though technically, developing-country debtors have promptly repald official debt, in most cases official creditors have made new loans in excess of any principal and interest repayments due. [See Bulow and Rogoff (1988)].

In the second set of regressions reported in Table 2 , the dependent variable includes only external debt owed to private creditors. Note that the coefficlents are always larger than one and the difference is significant over the full sample. ${ }^{3}$ Again, this simple relation explains a very large share of the varlation in external borrowing across countries, and the coefficients are relatively stable across regimes. ${ }^{4}$

2Nepal, which had zero private debt per capita, had to be excluded when the regressions were run in logs. Because it is poor, Nepal's exclusion biases the estimated coefficients downwards.

3 The results are quite robust to excluding trade credits and/or short term debt from the regressions. However, when "Micronesian" countries with populations under one mililon are included, the coefficients become smaller and the standard errors larger.

We also ran a regression that included the growth rate of per caplta GNP from 1980 to 1986 as a proxy for expected productivity change. The varlable, however, was unimportant. One can also interpret the regional regressions as a crude attempt to control for differences in expected productivity across countrles - the idea being that, while technology may differ between Brazil and Nigeria, it is less likely to significantly differ between Brazli and Argentina. Obviously, it would be desirable to explore the dynamics of the 
We chose the year 1980 because after the debt crisis began in 1982. the correspondence between book value and the market value of loans becomes much weaker. 5 There did not exist a secondary market for bank loans as of 1980 . but most of the private loans were indexed to short-term interest rates. Thus any capltal gains or losses would malnly have to Involve soverelgn risk. The fact that most debtor natlons were st11l recelving new funds in 1980 suggests that expectations of default were still quite low. Almost all soverelgn debt to private creditors is of equal priority (for a rationale see Bulow and Rogoff (1988)), so countries can generally only get new loans only if their old loans are valued near par. 6

\section{A Small-Country Model with Agency Costs of Investment}

our goal throughout is to provide the simplest possible model capable of 1llustrating our maln points. Before turning to the two-country case, we first develop and analyze a small country framework. We consider an open economy Inhabited by a large number of Identical Individuals; the economy is small in the sense that it cannot affect the world interest rate. There are two perlods and one good. The representative Individual is risk neutral and cares only about consuming in period two:

$$
\mathrm{U}(\mathrm{c})=c,
$$

external debt-GNP relation more fully, but unfortunately short-term debt data for years prior to 1980 is suspect.

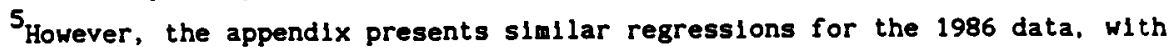
simllar results.

${ }^{6}$ Our results do not include direct investment, since Including this would not be in the splrit of the asymmetric information model of section III. However, we note that for within Africa and Asla, direct investment was small relative to debt. For South America, It was somewhat larger, though still small relative to debt. 
where $c$ is her second-perlod consumption.

Entering perlod one, each person is endowed with W unlts of the consumption good. ${ }^{7}$ There exist two ways to convert this endowment into final period consumption. The first option is to lend abroad at the (gross) world riskless interest rate $r$; the alternative is to invest in a risky technology. In particular, each person in the country has a project. All projects are Identical ex ante, and yield ex post returns as follows: $k$ units invested in period one yleld $\theta$ unlts of second-period output with probability $\pi(k)$, and zero units with probability $1-\pi(k)$. That is,

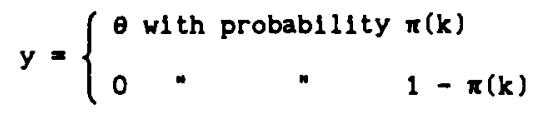

where $y$ is second-perlod output. The function $x(\cdot)$ is increasing, strictly concave and twice continuously differentlable, with $\pi(0)=0, \pi(\infty)=1$, and $r / \theta<\pi^{\prime}(0)<\infty^{8}$ Thus, investment ralses the probability that the Individual's project wlll yield a hlgh level of output, and the marginal expected return to investment is diminishing. ${ }^{9}$ We assume that output realizations are independent across the projects of different individuals.

If an individual wants to invest more than her endowment in her project,

$7_{W}$ can include any future income which is collateralizable. The distinction between current and future endowment is not important here. It is important in the two-country case since the world equilibrium will depend on the total supply of current endowment; see below.

$8 \pi^{\prime}(0)>r / \theta$ is needed to guarantee that it is optimal to invest under perfect information. It is not essential that $\pi^{\prime}(0)$ be finlte, but introducing this restriction makes the exposition a bit simpler.

${ }^{9}$ It is easy to generalize the results to a technology with a large set of possible output realizations. We choose the two-point distribution for ease of exposition. 
then she must raise funds from the world capltal market; that is,

$$
W+b \geq \mathbf{k}
$$

where $b$ is the amount she borrows. In return for this amount, she issues a state-contingent security whlch pays $z^{g}$ in the event the project yields the good outcome, and $z^{D}$ in the event of the bad outcome. The security must offer lenders the market rate of return $r$, so that

$$
\pi(k) Z^{g}+[1-\pi(k)] Z^{b}=r b
$$

The left-hand side of (4) is the expected payment to lenders.

The individual's expected second period consumption is given by

$$
E\{c\}=\pi(k)\left[\theta-z^{g}\right]-[1-\pi(k)] Z^{b}+r[W+b-k]
$$

where the last term is the individual's return from risk-free investments abroad, and the first two terms represent the expected net return on her project.

The information structure is as follows: Lenders may observe a borrower's initlal wealth and the total amount she borrows. What the borrower does with the funds, however, is her private knowledge. In particular, she may secretly lend abroad rather than invest in her project. Whereas investment is unobservable, lenders can freely observe realized output. The production function $\pi(\cdot)$ is common knowledge.

If there were no information asymmetries, the Individual would invest to the point where the expected marginal project return equals the world interest rate. Let $k^{*}$ denote this first-best level of investment; thus

${ }^{10}$ It is not necessary to assume that lenders are risk neutral, but only that idiosyncratic project risk be diversiflable in world capltal markets. 


$$
z^{\prime}\left(k^{*}\right) \theta=r
$$

Under asymetric information, however, it is not generally possible to implement the first best allocation because the borrower's choice of investment $k$ is not verifiable. ${ }^{11}$ Contracts can be conditioned only on realized output $y$, and not on $k$. Given any output-contingent payofis $\left(z^{g}, z^{b}\right)$ specifled by the contract, the borrower will plck $k$ to maximlze her expected consumption, given by (5). Thus she will equate her expected marginal gain from investing with her opportunity cost of (secretly) holding assets abroad 12

$$
x^{\prime}(k)\left[\theta-\left(Z^{g}-z^{b}\right)\right]=r
$$

So long as $Z^{9}$ differs from $Z^{b}$, $k$ will differ from its first-best optlmum value $k^{*}$, given by (6). The problem is that the borrower's marginal benefit from investing depends not only on the marginal gain in expected output, but on the change in her expected obligation to lenders, as well. We will subsequently refer to (7) as the "Incentive constraint."

If the borrower could promise lenders a flxed payment $z^{q}=z^{b}=r\left(k^{*}-W\right)$ then [by (7)] she would invest the first best amount $k^{*}$. This is not feaslble, however, since the project yields nothing in the bad state. Since the borrower's consumption must be non-negative. an important constraint on the form of the contract is

$$
z^{b} \leq 0
$$

${ }^{11}$ The incentive problem emerging here is classifled as moral hazard because the informational asymmetry arises after contracting. See Dixit (1987) for an application to international trade.

${ }^{12}$ The analysis would be qualitatively simllar if the borrower had the option of secretly consuming in perlod one instead of secretly lending abroad. 
For the case where $W<k^{\bullet}$ the optimal incentive compatible contract is found by choosing $z^{a}, z^{b}, b$, and $\dot{k}$ to maxinize (5) subject to (3), (4), (7) and (8). The solution is as follows ${ }^{13}$ : The contract pays lenders zero in the bad state, so that ( 8 ) is binding. (More generally, the contract always pays lenders the maximum feasible amount in the bad state.) This serves to minimize the spread between $z^{9}$ and $z^{b}$, thereby minimizing the difference between the borrower's decision rule for $k$ [eq. (7)] and the soclally efficient rule [eq. (6)]. ${ }^{14}$ similarly, equation (3) is binding; $w+b=k$. Thus, in equilibrium, the borrower does not secretly lend abroad. Borrowing more than is essential to finance $k$ would ralse the gap between $Z^{g}$ and $Z^{b}$. Since (3) and (5) hold with equality for the information-constrained case, one can use these equations to eliminate $b$ and $z^{b}$ from (4) and (7). The result is the following two equations, which determine $k$ and $z^{g}$ :

$$
\begin{array}{ll}
\pi^{\prime}(k)\left[\theta-z^{g}\right]=r, & \text { IC curve } \\
z^{g}=r(k-W) / k(k) & \text { IR curve }
\end{array}
$$

Equation (9) is the Incentive constraint, and is drawn as the curve IC in Figure 1. It is downward sloping. A rise in $Z^{9}$ lowers the borrower's expected marginal gain from investing and therefore must be offset by a decline in $\mathrm{k}$. The curve intersects the vertical axis at a value of $z^{g}$ which lies between zero and $\theta$ (recall that $r / \theta<\pi^{\prime}(0)<\infty$ ). It intersects the horizontal axis at $k^{*}$ since eq. (9) resembles eq. (6) when $z^{g}$ equals zero. Equation (10) is the constralnt that lenders must recelve the market rate of

13 See the Appendix for detalls.

${ }^{14}$ The Idea that informational asymmetries can affect an individual firm's investment strategies and financlal structure originated $w i$ th Jensen and Meckling (1976). 
Figure 1

\section{EQUILIBRIUA IN THE SYALL COUNTRY CASE}

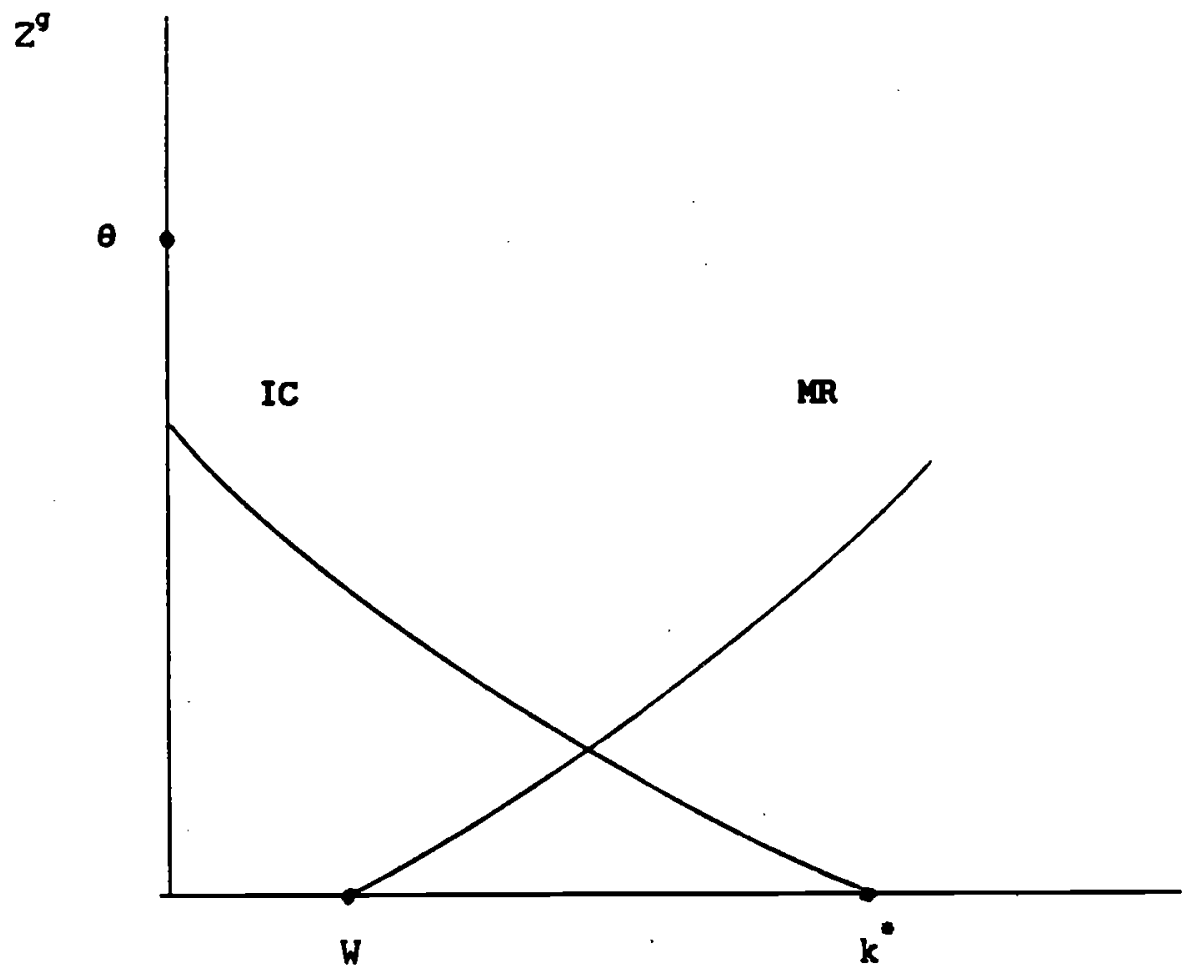


return, and $1 \mathrm{~s}$ labeled as the MR curve. It $1 \mathrm{~s}$ upward sloping. ${ }^{15}$ when $k$ rises, borrowing goes up; this means $z^{g}$ must rise since $z^{b}$ cannot adjust. The curve intersects the horlzontal axis at $k$ equal to $W$. It lies above the horlzontal axis at $k^{*}$ since $k^{*}>W$.

Investment in the Information-constralned case must be below its first best value $k^{*}$. The result that $k<k^{*}$ follows Immedlately from a comparison of (6) and (9), as well as from Inspection of Figure 1 . If $k$ is below $k$, then ex post per cap1ta output, $\theta \pi(k)$, must lle below 1 ts first best value, $\theta \pi\left(k^{*}\right) .16$ An 1.mplication 1s that both per caplta Investment and per caplta output w1ll depend on per caplta wealth. A rise in W shifts the MR curve downward In Flgure 1 and leaves the IC curve unchanged, thereby ralsing $k$ and lowering $Z^{9} \cdot 17$ Additlonal wealth Increases the amount of internal funds avallable to the borrower; so for a given level of Investment, $Z^{g}$ declines, mitigating the Incentive problem. Investment rises, In accordance with eq. (9), thus raising output as well. 18

Now consider the link between external borrowing and country wealth.

${ }^{15}$ The slope of the $\mathrm{WR}$ curve equals $[r / \pi(k)](1-\phi(k)(1-W / k)]$; where $\phi(k)$ is the ratlo of the marginal product of capltal to the average product, given by $\pi^{\prime}(k) /(\pi(k) / k)$. Since $0<\phi(k)<1$ and since $W<k$ along the MR curve, the slope must be positive.

${ }^{16}$ Because the productivity risks are Independent across investment profects, and because the number of projects is large, there is no aggregate risk.

${ }^{17}$ The result that 1ncreases in borrower net worth stimulate investment when informational problems are present is quite general; see Bernanke and Gertler (1989). For some emplr1cal support, see Fazzar1, Hubbard and Petersen (1988).

${ }^{18}$ The effect of a change in $W$ on $k$ is given by

$$
\frac{\partial k}{\partial W}=\pi^{\prime}(k) Z_{3}^{g} /\left[\left(\pi^{\prime \prime}(k) / \pi^{\prime}(k)\right) r-\pi^{\prime}(k) Z_{2}^{g}\right]>0
$$

where $z^{g}(r, k, W)=r(k-W) / \pi(k)$, so that $z_{2}^{g}>0$ and $z_{3}^{0}<0$. 
Let $x$ denote per capita borrowing fron abroad, equal in this case to $k$ - $W$. Then, from differentiating eqs. (9) and (10), one obtains

$$
\frac{d x}{d W}=\left[1-\phi(k)(1-W / k)-\frac{\pi^{\prime \prime}(k) \pi(k)}{\pi^{\prime}(k)^{2}}\right]^{-1}-1
$$

where,

$$
0<\phi(k)=\pi^{\prime}(k) /[(k) / k]<1
$$

External borrowing will rise with $W$ if a dollar increase in wealth induces more than a dollar increase in investment. This w111 be the case if diminishing returns set in slowly, 1.e., $\pi^{\prime \prime}(k)$ is small relative to $\pi^{\prime \prime}(k)$. (Inspection of eq. (11) indicates that the magnitude of $\frac{\partial x}{\partial W}$ varies inversely with the absolute value of $\pi^{\prime \prime}(k) / \pi^{\prime}(k)$.) Thus, to the extent that per capita GNP can be considered a proxy for per-capita wealth, the framework is capable of explaining the positive relation between external borrowing and output for developing countries, documented in section II. The informational problem is of course key to the result; when the incentive constraint is not binding, external borrowing simply declines a dollar for each dollar increase in wealth; this occurs since investment is no longer influenced by changes in $W$.

A corresponding result is that the spread between the marginal product of capital and the world riskless interest rate will vary across countries, and w11 in particular be larger the poorer the country. Note that cross-country differences in marginal products of capital may arise here even though the world capital market is perfectly integrated (the riskless rate is the same everywhere). 19

Finally, consider how changes in the world interest rate influence

${ }^{19}$ Thus our model is completely consistent with Frankel and MacArthur's (1988) finding that covered interest differentlals are relatively small for many LDCs. 
1nvestment. As $r$ goes up, the IC curve shifts to the left. The borrower's opportunity cost of Investing rises, so for any glven value of $z^{q}, k$ must decline. The in curve moves inward as well. Some combination of a rise in $Z^{\circ}$ and a fall in $k$ is necessary for lenders to cont lnue to recelve a competitive return. The Interest-elasticity of Investment in the Information-constralned case may or may not be greater than in the full Information case. It is greater if $\mathrm{d} Z^{g} / \mathrm{dr}>0$. Thls w11l $11 \mathrm{kely}$ be the case if the initial amount borrowed, $k-H$, is large or if the production function Is sufflclently concave so that the decline in $k$ is not enough to offset the h1gher rate of interest. 20

None of the countries 11 sted in Table 1 represents more than a tiny fraction of the world's GNP. However, taken together, they are economically larger than Japan. Therefore, for some 1ssues involving mult1-lateral transfers of wealth (e.g., due to a global restructuring of Third World debt). It is of Interest to analyze the general equilibrlum implications of these nations' capltal market activities.

\section{The Two-Country General Equilibrium Case}

Suppose there are two countries of equal population size, country $R$ ("rich") and country $P$ ("poor"). In each country, $\alpha$ percent of the indlviduals are "entrepreneurs" and 1- $\alpha$ percent are "lenders." All Individuals have the same utillty function, given by equation (1). That is,

${ }^{20}$ The adjustment of $k$ in response to a change in $r$ is given by

$\frac{d k}{d r}=\left[1+\pi^{\prime}(k) Z_{1}^{g}\right] /\left[\left(\pi^{\prime \prime}(k) / \pi^{\prime}(k)\right) r-\pi^{\prime}(k) Z_{2}^{g}\right]<0$ where $z^{g}(r, k)=r(k-W) / \pi(k)$, so that $z_{1}^{9}>0$ and $z_{2}^{9}<0$. 
they are risk neutral and care only about second perlod consumption. Entering the first perlod, all entrepreneurs in the poor country are endowed with $w^{p}$ units of the good, and all lenders are endowed with $W^{P L}$ units. Simllarly, entrepreneurs and lenders in the rich country are endowed with $W^{R}$ and $W^{\text {RL }}$ units, respectively. For the time beling, the only restriction we need impose is that $W^{P}<W^{R}$.

Each entrepreneur owns and manages a risky investment project. The project technology is the same across entrepreneurs and across countries, and is given by equation (2) above. As before, if an entrepreneur wants to invest more than her endowment she has to borrow, so that equation (3) st111 applies. Lenders do not have projects; their only optlon is to lend to entrepreneurs. 21

The information structure is the same as in the small country case. Lenders observe a project's reallzed output, but cannot observe the capital 1nput. They cannot directly see whether the entrepreneur is secretly lending to other entrepreneurs. 22

If there were no Information asymmetrles, the following three equations would characterize the world equllibrium:

$$
\begin{gathered}
\pi^{\prime}\left(k^{P *}\right) \theta=r \\
\pi^{\prime}\left(k^{R^{*}}\right) \theta=r \\
\alpha\left(k^{R^{*}}+k^{P *}\right)=\alpha\left(w^{P}+w^{R}\right)+(1-\alpha)\left(w^{P L}+w^{R L}\right)
\end{gathered}
$$

where the $P$ and $R$ superscripts denote the countries, and the ''s denote the

${ }^{21}$ Without lenders, entrepreneurs would not be borrowers in the world general equilibrium.

${ }^{22}$ Note that entrepreneurs may secretly rechannel their investment funds either directly, or through a (zero-profit) intermediary. 
full information equilibrium. The main difference from the small country case is of course that the world interest rate $r$ is endogenous. It depends on technology and the total world endowment. Since the technologies are the same, $k^{p \bullet}$ equals $k^{R^{*}}$. Under perfect information, the pattern of investments is independent of the pattern of endowments.

Under asymmetric information, the following five equations characterize the world equilibrium:

$$
\begin{gathered}
\pi^{\prime}\left(k^{P}\right)\left[\theta-z^{q P}\right]=r \\
\pi^{\prime}\left(k^{R}\right)\left[\theta-z^{q R}\right]=r \\
z^{q P}=r\left[k^{P}-w^{P}\right] / \pi\left(k^{P}\right) \\
z^{q R}=r\left[k^{R}-w^{R}\right] / \pi\left(k^{R}\right) \\
\alpha\left(k^{P}+k^{R}\right)=\alpha\left(w^{P}+w^{R}\right)+(1-\alpha)\left(w^{P L}+w^{R L}\right) \quad \text { w curve }
\end{gathered}
$$

Equations (15) and (16) correspond to equation (9) for the small country case, and equations (17) and (18) correspond to equation (10). Equation (19) is the condition that the total demand for investment capital must equal the world supply, and is drawn as the negatively-sloped wh curve in Figure 2.

Investment in the poor country is now less than in the rich country. Combining equations (15) through (18) yields

$$
r=p\left(k_{-}^{P}, W^{P}\right) \theta=p\left(k^{R}, W^{R}\right) \theta \quad p p \text { curve }
$$

where the function $\rho(\cdot, \cdot)$ is given by

$$
\rho\left(k^{J}, w^{J}\right)=\frac{\pi^{\prime}\left(k^{J}\right)}{1+\pi^{\prime}\left(k^{J}\right)\left[k^{J}-w^{J}\right] / \pi\left(k^{J}\right)}, \quad J=P, R \text {. }
$$

As indicated in equation $(20), \rho_{1}<0$ and $\rho_{2}>0$. It follows immediately tha 
Figure 2 .

EQUILIBRIUA IN THE TWO COUNTRY CASE

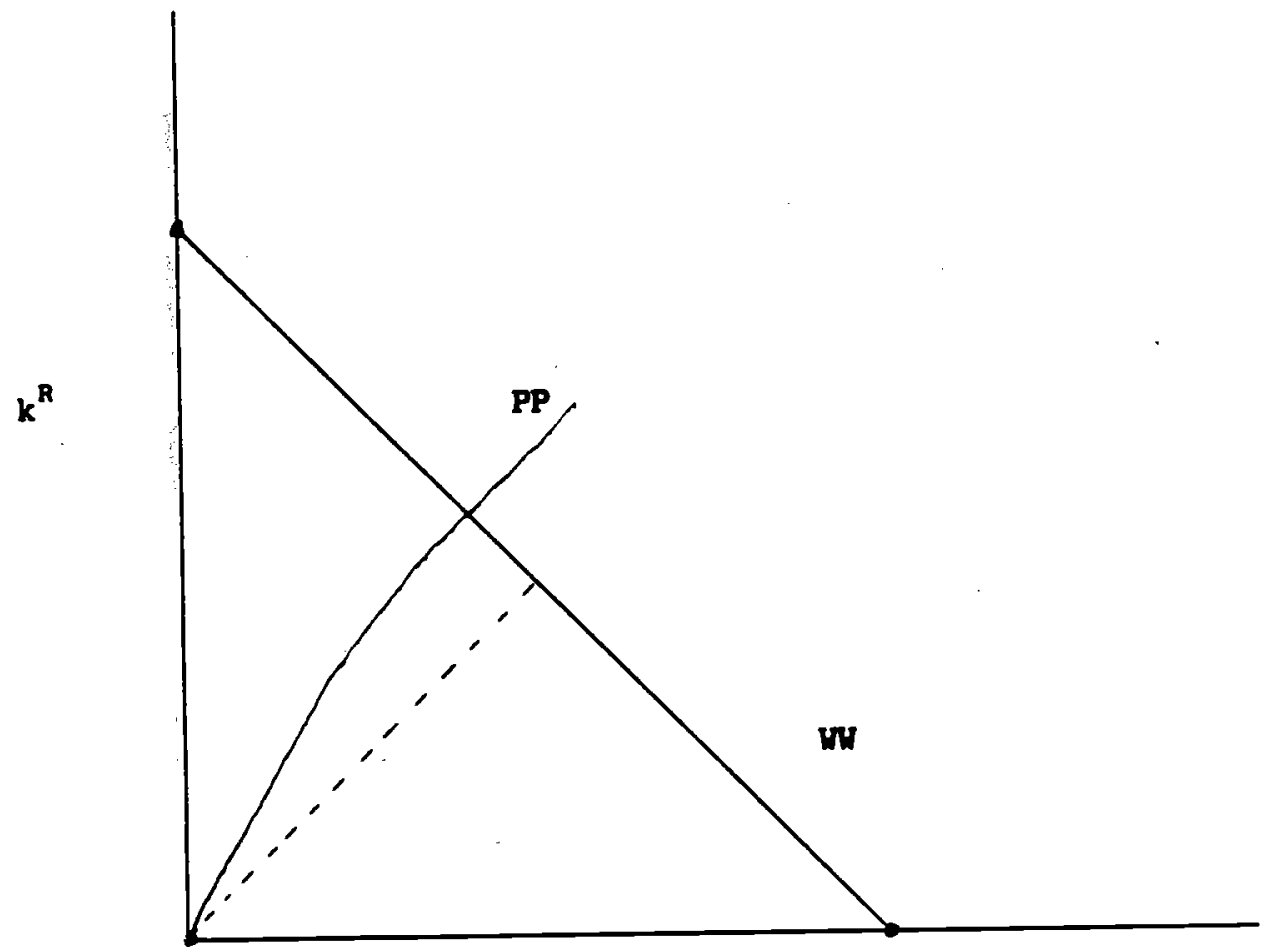

$$
\mathbf{k}^{\mathbf{P}}
$$


$k^{P}<k^{R}$, since $W^{P}<w^{R}$. Because investment is distorted, world output is lower than in the perfect information case. The world interest rate must al be lower; this is easily demonstrated by comparing conditions (16) and (13), and noting that $k^{R}>k^{R^{*}}$, and that $z^{\mathcal{G}}>0$. Thus lenders must be worse off under asymmetric information. Equation (20) is drawn as the positively-slop pp curve in Figure 2.

In general, the pattern of world investment depends on the agency costs of lending in one country relative to the other, which in turn depends on th net asset positions of entrepreneurs across countries. 23 To 11lustrate this point, suppose that the wealth of rich country entrepreneurs improves, but that both total world endowment and the endowments of poor country entrepreneurs remaln unchanged. Consider, for example, a redistribution of wealth in the rich country from lenders to entrepreneurs. This corresponds an upward rotation in the $\rho p$ curve in Figure 2; the wh curve remains unchanged. $k^{R}$ rises and $k^{P}$ falls. The decline in the agency costs of finan in the rich country induces a "siphoning" of investment funds from the poor country. 24 The increased demand for funds by rlch country entrepreneurs driv up the world interest rate, drawing capital out of the poor country. [Inspection of eq. (20) indicates that $\partial r / \partial W^{R}>0$ since $k^{P}$ declines and $W^{P}$ unchanged. I Entrepreneurs in the poor country lose rents as a result of the

${ }^{23}$ An Important difference between our model and earller frameworks emphasizin, capital market frictions (e.g., Persson and Svenson (1987)) is that the imperfections and the forms of the financial contracts are derived endogenously. An important exception is Greenwood and Williamson (forthcoming) who develop a monetary model of international business fluctuations under incomplete information. Another related paper is Samolyk (1988), who studies the transmission of regional disturbances in financial markets.

${ }^{24}$ See the appendix for an analytical derivation. 
capital flight. This loss of rents is aggravated by the rise in the world interest rate. Lenders in the poor country benefit from the rise in interest rates but as long as the poor country is a net borrower, its national income must fall.

A fall in the wealth of poor country entrepreneurs simllarly induces siphoning of capital from the poor to the rich country. The reduced efficiency of lending in the poor country causes funds to flow out to the world capital market. In contrast to the previous case, the world interest rate declines. [Inspection of eq. (20) indicates that $\partial r / \partial W^{P}<0$ since $k^{R}$ increases while $W^{R}$ remains unchanged.] The shift of investment funds from the high marginal product of capital poor country to the low marginal product of capital rich country depresses the equllibrium interest rate.

Now consider a transfer of wealth from the poor country to the rich. In particular, suppose that_r units of wealth are taken from each citizen of the poor country and are distributed evenly among the citizens of the rich country. This transfer can also be graphed as an upward rotation of the $p \rho$ curve in Figure 2. However, for a given change in $W^{R}$ the $p \rho$ curve shifts by more than for our earlier example in whlch the transfer came from rich country lenders. Both the increase in $W^{R}$ and the decline in $W^{P}$ induce $k^{R}$ to $r$ ise and $k^{P}$ to fall. The net effect on the world interest rate 1s ambiguous; greater $W^{B}$ tends to move the interest rate up while less $W^{P}$ moves 1 t down, as discussed earller. Note that under perfect information a simllar transfer of wealth would affect neither investment nor the interest rate (see eqs. (12) (14)).

The wealth transfer naturally imposes a direct cost on the poor country. But there may be indirect costs as well. Holding constant the world interest rate, entrepreneurs in the poor country lose additlonally because their 
project rents decline due to the reduction in investment. Thus, to the exter. that the movement in the world interest rate is not large, the indirect effects always magnify the costs of the transfer. If the change in the interest rate is large (owing to highly concave production functions) then th: exact effect on the poor country's national income depends on whether it is a net debtor or creditor in the world capltal market. However, if the poor country is small, the movement in $r$ is negligible so that the capital market problems always magnify the costs of weal th transfers.

This model accordingly produces a "transfer" problem in the sense that the cost to a country of paying a forelgn debt may exceed the face value of the payments. Here the transfer problem relates to intertemporal trade rathe than contemporaneous trade, as in the classic debate between Keynes and Ohl In It arises because the distribution of wealth affects the allocation of investment, due to information asymmetries.

As another varlation on thls theme, consider a shock which increases the Initlal endowment of all individuals in the rlch country, thus increasing the total supply of Investment funds avallable to the world capital market. Under perfect information, capltal investment would rise the same in each country. But under asymmetric information, there will be a siphoning effect since the wealth of rich country entrepreneurs rises as well. Thus the increase in Investment $w 111$ be greater in the rich country. and it is even concelvable that investment may decline in the poor country.

Note that in a dynamlc context, the relevant measure of a borrower's wealth, W, Includes not only liquid assets, but any collateralizable expected future profits as well. 25 Thus good news about future business conditions in

25 See Gertler (1988), who studles a closed economy with repeated production and asymmetric information where entrepreneurs enter long-term financial 
the rich country can also induce the "siphoning" effect described above.

Finally, we consider a shock to world productivity, $\theta$. By inspection of of equation (20), we see that a world productivity shock has no effect on the distribution of investment capital, since $\theta$ factors out of both sides. As in the full information case, the $r$ ise in $\theta$ increases per capita world output and the world interest rate $r$.

\section{v. Conclusions}

Across developing countries, external debt to private creditors rises more than proportionately with income. Our simple model of international finance under asymetric information provides one natural explanation of this phenomenon. There are, however, other plausible theories. Sovereign risk is clearly an important feature of developing-country borrowing, and modern bargaining-theoretic analyses of sovereign lending suggest a strong relation between income and external debt. In the standard models, the relationship is 26

generally proportional. It would be interesting to extend the present model

to include both sovereign risk and asymmetrically-informed borrowers and 27

lenders. The Marshall-Romer model of growth under Increasing returns to scale yields a very different rationale for why the income elasticity of external borrowing might exceed unity [Romer (1989)]. One testable difference between the Marshall-Romer model and the one developed here is that our

contracts with lenders.

${ }^{26}$ See Bulow and Rogoff (1989), or Fernandez and Rosenthal (1988).

27 The model of Atkeson (1988) does incorporate both soverelgn risk and moral hazard, though the private information in his model is at the level of the government and not the individual. 
framework would predict that marginal products of capltal are higher in poor countries. Our framework yields a similar prediction for borrowing and lending spreads.

It is important to stress that although there are capital market imperfections in the model, government intervention cannot be Pareto improving. To achieve Pareto improving interventions the public agency would have to be more efficient than private lenders in overcoming the informational problems.

Finally, we note that the present analysis suggests an alternative explanation for the Feldstein-Horloka (1980) puzzle that savings and investment tend to be highly correlated across countries. 28 In a world of perfect information, if a small country's endowment increases without any corresponding increase in its productive opportunitles, it will invest any increased savings abroad. In a model where borrowing is subject to informational problems, however, a large part of the increase in savings may be invested domestically.

${ }^{28}$ Feldstein and Horloka appeal to imperfectly integrated world capital markets to explain their puzzle. Obstfeld (1986), Stulz (1986) and Tesar (1988) show how the saving-investment correlation could arise in a frictionless setting if technology shocks are dominant. 


\section{APPDNDIX}

The formal problem which jolntly determines how much the entrepreneur Invests and her contractual arrangement with lenders is as follows: Choose $k$, b. $z^{g}$ and $z^{b}$ to solve

$$
\max \pi(k)\left(\theta-z^{\theta}\right)-[1-\pi(k)] z^{b}+r(w+b-k)
$$

subject to

$$
\begin{gathered}
\pi(k) Z^{g}+[1-\pi(k)] Z^{b}=r b \\
\pi^{\prime}(k)\left[\theta-\left(Z^{g}-Z^{b}\right)\right]=r \\
0 \geq z^{b} \\
W+b-k \geq 0
\end{gathered}
$$

Let $\mu, \gamma, v$, and $\psi$ be the (non-negative) multipliers assoclated with (A2)

- (A5), respectively. Then the first-order necessary conditions with respect to $k, b, Z^{g}$ and $Z^{b}$ are given by

$$
\begin{gathered}
\mu \pi^{\prime}(k)\left(z^{g}-z^{b}\right)+r r \pi^{\prime \prime}(k) / \pi^{\prime}(k)-\psi=0 \\
\psi=r(\mu-1) \\
\pi(k)(\mu-1)-r \pi^{\prime}(k)=0 \\
{[1-\pi(k)](\mu-1)+\gamma \pi^{\prime}(k)-v=0}
\end{gathered}
$$

Recall that $k^{*}$ is the first best level of capital Investment, given by 


$$
\mathbf{x}^{\prime}\left(\mathbf{k}^{\bullet}\right) \theta-r=0
$$

(whlch corresponds to eq. (6) in the text). Then we have:

Proposition 1: (1) If $W=k^{*}, k=k^{*}$; (11) if $W<k^{*}, k^{*} k^{*}$.

Proof: Part (1) is obvlous; since $W=k^{*}$ the entrepreneur has

sufficient wealth to undertake the unconstrained optimal investment without borrowing; she will lend any residual wealth. Part (11) can be proven by contradiction. Suppose $\mathrm{W}^{\circ} \mathbf{k}^{\bullet}$ and $k=k^{\bullet}$. Then (A5) implies $\mathrm{b}>0$. If $\mathrm{b}>$ 0 . then (A2) and (A4) Imply $z^{\circ}>z^{\circ}$. If $z^{\circ}>z^{\circ}$ then (A3) and (A10) imply $k<$ $k^{\bullet}$, whlch leads to a contradiction. Q.E.D.

Proposition 2: If $w<k^{\bullet}, k$ is given jointly with $z^{9}$ by

$$
\begin{aligned}
& \pi^{\prime}(k)\left(\theta-z^{\theta}\right)=5 \\
& z^{\theta}=r(k-W) / \pi(k)
\end{aligned}
$$

where (A11) and (A12) correspond to eqs. (9) and (10) in the text.

Proof: If $W^{\circ}<\mathbf{k}^{\bullet}$ then $k^{\circ}<\mathbf{k}^{\bullet}$, from Proposition 1 . If $k^{\circ}<\mathbf{k}^{*}$ then $z^{g}>z^{b}$, from (A3) and (A10). It follows from (A6) - (A8) that $\mu>1$. This in turn implies that $\gamma, v$, and $\psi$ are positive. Thus (A4) and (AS) hold with equality. Using (A4) and (A5) to eliminate $Z^{b}$ and $b$ from (A2) and (A3) ylelds (A11) and (A12). Q.E.D.

Corollary: If $W<k^{*}, W<k<k^{\bullet}$.

Proof: $W<k^{*}$ implies $k<k^{*}$, from Proposition 1 . Proposition 2 then implies $z^{b}=0$. If $k<k^{*}$ and $z^{b}=0$, then $z^{q}>0$ from (A3). It follows from 
(A12) that $k>$ W. Q.E.D.

COMPARATIYE STATICS OF THE THO-COUNTRY CASE

From eqs. (19) and (20) in the text, $k^{n}$ and $k^{p}$ are determined jointly by the following two conditions:

$$
\begin{gathered}
\rho\left(k^{R}, w^{R}\right)=\rho\left(k^{P}, w^{P}\right) \\
\alpha\left(k^{R}+k^{P}\right)=\alpha\left(w^{R}+w^{P}\right)+(1-\alpha)\left(w^{R L}+w^{P L}\right)
\end{gathered}
$$

where

$$
\rho\left(k^{J}, w^{J}\right)=\rho^{J}=\frac{\pi^{\prime}\left(k^{J}\right)}{1+\pi^{\prime}\left(k^{J}\right)\left[k^{J}-W^{J}\right] / \pi\left(k^{J}\right)} \quad J=P, R
$$

so that $\rho_{1}^{J}<0$ and $\rho_{2}^{J}>0$.

Initially we assume that world wealth is held constant at $\bar{W}$ (think of the experiments as being wealth redistributions) so that (B4) temporarily replaces (B2):

$$
\alpha\left(k^{R}+k^{P}\right)=\bar{w},
$$

where $\bar{W}$ is a fixed number. Then,

$$
\begin{aligned}
\frac{\partial k^{R}}{\partial w^{R}}=-\frac{\partial k^{P}}{\partial w^{R}}=-p_{2}^{R} /\left(p_{1}^{R}+p_{1}^{P}\right)>0 \\
\frac{\partial k^{R}}{\partial w^{P}}=-\frac{\partial k^{P}}{\partial w^{P}}=p_{2}^{P} /\left(p_{1}^{R}+p_{1}^{P}\right)<0
\end{aligned}
$$

Inspection of eq. (20) indicates that $\frac{\partial r}{\partial W^{R}}>0$ (since $k^{P}$ declines and $w^{P}$ is unchanged), while $\frac{\partial r}{\partial W^{p}}>0$ (since $k^{R}$ declines and $W^{R}$ is unchanged).

Next note that national income per capita for country $J, y^{J}$, is gtven by 


$$
\begin{aligned}
y^{J} & =\alpha\left[\pi(k) \theta-r\left(k^{J}-w^{J}\right)\right]+(1-\alpha) r w^{\Omega} \\
& \left.=\alpha \alpha(k) \theta+r\left[\left(\alpha w^{J}+(1-\alpha)\right) w^{\Omega}\right)-\alpha k^{J}\right]
\end{aligned}
$$

Using the previous results in conjunction with (B7), one can readily determin the Impact of changes in $W^{R}$ and $W^{P}$ on the national income of each country. For example, it is stralghtforward to show that a rise in $w^{R}$ may lower the national income of the poor country, and definitely does so if the poor country is a net debtor in the world capital market (1.e., if $\{[\alpha\}$ + $\left.\left.(1-\alpha)) w^{\Omega}, \alpha k^{J}\right\}<0\right)$.

Now suppose the total stock of world endowment is permitted to change. For simplicity, let $w^{R}=w^{\text {PL }}$ and $w^{P}=w^{p L}$, so that (B2) becomes

$$
\alpha k^{R}+\alpha k^{P}=w^{R}+w^{P}
$$

Then.

$$
\frac{\partial k^{R}}{\partial w^{R}}=\left(-\alpha p_{2}^{R}+p_{1}^{P}\right) / \alpha\left(p_{1}^{R}+p_{1}^{P}\right)>0 ; \frac{\partial k^{P}}{\partial w^{R}}=\left(\alpha p_{2}^{R}+p_{1}^{R}\right) / \alpha\left(p_{1}^{R}+p_{1}^{P}\right) ?
$$

Under perfect Information, (B8) together with eqs. (12) and (13) imply that $\frac{\partial k^{R}}{\partial W^{R}}=\frac{\partial k^{P}}{\partial w^{R}}=1 / 2 \alpha$. Equation (B9) Indicates that under asymetric information $\frac{\partial k^{R}}{\partial W^{R}}>1 / 2 \alpha$ if $\rho_{1}^{P}$ is not too much smaller than $\rho_{1}^{R}$ or if $\rho_{2}^{R}$ is sufficiently large. 29 The term $-\alpha p_{2}^{B}$ in the numerator of (B9) reflects the influence of the siphoning effect. If the siphoning effect is very strong ( $\rho_{2}^{R}$ is large), $\frac{\partial k^{P}}{\partial w^{R}}$ may be negative.

${ }^{29}$ Note that $p_{1}^{R}=p_{1}^{P}$ when $W^{R}=W^{P}$. 
DOLLARS PER CAPITA

\begin{tabular}{|c|c|c|c|}
\hline & GNP & $\begin{array}{l}\text { External Debt } \\
\text { to Private Lenders }\end{array}$ & $\begin{array}{c}\text { Total } \\
\text { External Debt }\end{array}$ \\
\hline 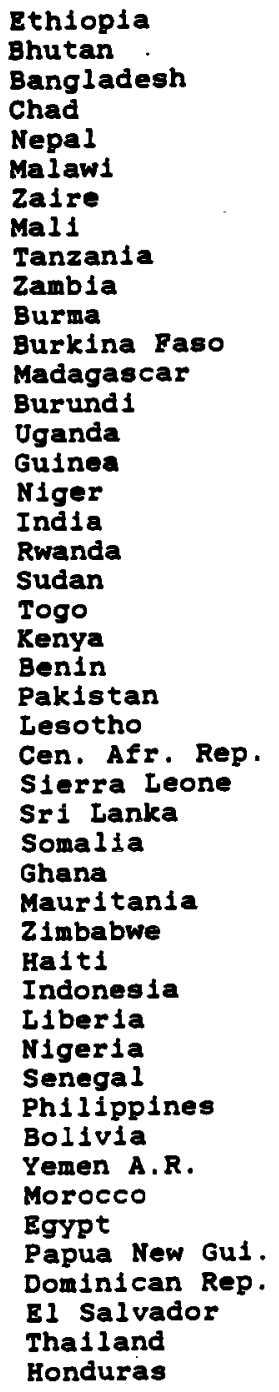 & $\begin{array}{l}116 \\
132 \\
152 \\
157 \\
138 \\
162 \\
164 \\
183 \\
199 \\
204 \\
206 \\
235 \\
236 \\
257 \\
275 \\
282 \\
285 \\
297 \\
304 \\
308 \\
313 \\
327 \\
332 \\
336 \\
343 \\
344 \\
345 \\
389 \\
393 \\
398 \\
400 \\
415 \\
415 \\
429 \\
456 \\
468 \\
531 \\
543 \\
590 \\
619 \\
619 \\
660 \\
106 \\
774 \\
779 \\
286 \\
792\end{array}$ & $\begin{array}{r}9 \\
0 \\
3 \\
13 \\
3 \\
20 \\
38 \\
16 \\
35 \\
232 \\
3 \\
7 \\
46 \\
10 \\
9 \\
31 \\
87 \\
13 \\
6 \\
142 \\
56 \\
69 \\
122 \\
27 \\
8 \\
19 \\
40 \\
61 \\
54 \\
32 \\
10 \\
190 \\
21 \\
145 \\
143 \\
179 \\
88 \\
344 \\
401 \\
46 \\
274 \\
233 \\
525 \\
194 \\
58 \\
200 \\
223\end{array}$ & $\begin{array}{r}49 \\
16 \\
78 \\
46 \\
44 \\
155 \\
220 \\
206 \\
181 \\
815 \\
96 \\
99 \\
285 \\
114 \\
29 \\
249 \\
230 \\
54 \\
70 \\
431 \\
349 \\
233 \\
226 \\
149 \\
119 \\
166 \\
165 \\
252 \\
485 \\
189 \\
934 \\
669 \\
130 \\
258 \\
633 \\
248 \\
456 \\
515 \\
844 \\
328 \\
830 \\
763 \\
205 \\
548 \\
349 \\
356 \\
662\end{array}$ \\
\hline
\end{tabular}




$\begin{array}{lrrr}\text { Cote D'Ivolre } & 852 & 715 & 1097 \\ \text { Guatemala } & 857 & 142 & 337 \\ \text { Botswana } & 874 & 38 & 345 \\ \text { Congo } & 907 & 1382 & 2079 \\ \text { Jamaica } & 918 & 315 & 1709 \\ \text { Paraguay } & 937 & 204 & 535 \\ \text { Cameroon } & 989 & 168 & 351 \\ \text { Ecuador } & 1050 & 641 & 956 \\ \text { Turkey } & 1123 & 331 & 652 \\ \text { Tunisia } & 1129 & 282 & 788 \\ \text { Columbia } & 1155 & 293 & 526 \\ \text { Chile } & 1211 & 1286 & 1641 \\ \text { Jordan } & 1214 & 596 & 1179 \\ \text { Peru } & 1314 & 480 & 790 \\ \text { Mexico } & 1540 & 1072 & 1270 \\ \text { Costa Rica } & 1540 & 958 & 1696 \\ \text { Syria } & 1756 & 178 & 416 \\ \text { Brazil } & 1940 & 634 & 814 \\ \text { Uruguay } & 2000 & 986 & 1277 \\ \text { Panama } & 2159 & 1462 & 2213 \\ \text { Portugal } & 2248 & 1314 & 1604 \\ \text { Korea } & 2288 & 822 & 1124 \\ \text { Argentina } & 2397 & 1353 & 1602 \\ \text { Gabon } & 2569 & 1009 & 1374 \\ \text { Venezuala } & 2723 & 1903 & 1951 \\ \text { Algeria } & 2752 & 723 & 857 \\ & & & \end{array}$

Sources: World Bank, World Debt Tables: External Debt of Developing Countries, vol. II, 1988-89 ed., and International Monetary Fund, International Financial statistics.

Notes: Total external debt includes public and publicly guaranteed long-term debt, private nonguaranteed long-term debt, IMF credit, and short-term debt. External debt to private lenders includes long-term public and publicly-guaranteed debt to private creditors, private non-guaranteed long-term debt, and short-term debt. All of the World Bank's list of developing countries are included above, except those with 1986 populations under one million and 1986 GNPs over $\$ 3,000$. Communist countries are excluded; Lebanon and Malaysia are excluded due to insufficient data. 
TABLE A2

OLS Reressions of Debt/Capita on GNP/Capita for Developing Countries: 1986

$\log$ Total Extemal

Debt per Capita

All countries

Sub-Saharan

Africa

Latin America

and Caribbean

Asia
Constant

$-.68$

$-.21$

$-1.10$

$-3.09$ $\log G N P$

per Capita

1.04

(.09)

.99

(.19)

1.11

(23)

1.38

(20)
\# Observations

73

33

19

12
.69

.58

.82

$R^{2}$

.67

\begin{tabular}{|c|c|c|c|c|}
\hline $\begin{array}{l}\text { log Extemal Debt } \\
\text { to Private Lenders } \\
\text { per Capita }\end{array}$ & Constant & $\begin{array}{l}\log G N P \\
\text { per Capita }\end{array}$ & \# Obsenvations & $R^{2}$ \\
\hline All Countries & -6.35 & $\begin{array}{l}1.74 \\
(.13)\end{array}$ & 72 & .72 \\
\hline $\begin{array}{l}\text { Sub-Saharan } \\
\text { Africa }\end{array}$ & -5.05 & $\begin{array}{l}1.54 \\
(.29)\end{array}$ & 33 & .47 \\
\hline $\begin{array}{l}\text { Latin America } \\
\text { and Caribbean }\end{array}$ & -8.08 & $\begin{array}{l}200 \\
(.29)\end{array}$ & 19 & .73 \\
\hline Asia & -10.90 & $\begin{array}{l}245 \\
(.36)\end{array}$ & 11 & .83 \\
\hline
\end{tabular}

Africa: Benin, Botswana, Burkina Faso, Burundi, Cameroon, Central African Republic, Chad, Congo, Cote D'Ivoire, Ethiopia, Ghana, Guinea, Kenya, Lesotho, Liberia, Madagascar, Malawi, Mali, Mauritania, Niger, Nigeria, Rwanda, Senegal, Sierra Leone, Somalia, Tanzania, Togo, Uganda, Zaire, Zambia, Zimbabwe.

Latin America and the Caribbean: Argentina, Bolivia, Brazil, Chile, Columbia, Costa Rica, Dominican Republic, Ecuador, El Salvador, Guatemala, Haiti, Honduras, Jamaica, Mexico, Panama, Paraguay, Peru, Uruguay, Venezuela.

Asia: Bangladesh, Burma, India, Indonesia, Korea, Nepal, Pakistan, Papua New Guinea, Philippines, Sri Lanka, Thailand.

Other: Algeria, Egypt, Jordan, Morocoo, Portugal, Syria, Tunisia, Turkey, Yemen Arab Republic. 


\section{References}

Atkeson, Andrew, "Internatlonal Lending with Moral Hazard and Risk of Repudiation," Stanford Graduate School of Business mimeo, 1988.

Bernanke, Ben and Mark Gertler, "Agency Costs, Net Horth and Business Fluctuations," American Economic Revlew (forthcoming March 1989).

Bulow, Jeremy and Kenneth Rogoff, "A Constant Recontracting-Model of Sovereign Debt," Journal of Polltical Economy 97 (February 1989), 155-177.

Papers on Economic Activity: no. 2 (1988), 675-698.

Dixit, Avinash. "Trade and Insurance with Moral Hazard," Journal of International Economics 23 (November 1987), 201-220.

Fazzari, Stephen, Glenn Hubbard and Bruce Petersen, "Financing Constralnts and Corporate Investment," Brookings Papers on Economic Activity: no. 1 (1988), 141-195.

Feldstein, Martin and Charles Horioka, "Domestic Saving and International Capital Flows," Economic Journal 90 (June 1980), 314-329.

Fernandez, Raquel and Robert Rosenthal, "Sovereign-Debt Renegotiations: A Strategic Analysis," NBER Horking Paper No. 2597, (May 1988).

Frankel, Jeffrey and Alan MacArthur, "Political vs. Currency Premia in International Real Interest Rate Differentials, "European Economic Review 32 (1988) 1083-1121.

Gertler, Mark, "Financial Structure and Aggregate Economic Activity," Journal of Money, Credit and Banking 20 (August 1988, Part 2), 559-588.

, "Financial Capacity, Reliquification and Production in an Economy with Long-term Financial Arrangements," NBER Working Paper No. 2763 (November 1988).

Goldsmith, Raymond, Financlal Structure and Development, (New Haven: Yale University Press). 1969.

Greenwood, Jeremy and Stephen Hillamson, "International Financial Intermediation and Agregate Fluctuations under Alternative Exchange Rate Regimes," Journal of Monetary Economics, (forthcoming 1989).

Jensen. Michael and Hilllam Meckling. "Theory of the Firm: Managerial Behavior Agency Costs and Ownership Structure," Journal of Financial Economics 3 (October 1976), 305-360.

Keynes, John Maynard, "The German Transfer Problem," Economic Journal 39 (1929), 1-7.

Mckinnon, Ronald, Money and Capltal in Economic Development, (Washington D.C.: The Brookings Institute), 1973. 
Obtsfeld, Maurice, "Capital Mobility in the World Economy: Theory and Measurement," In Karl Brunner and Allan H. Meltzer (eds. ). CarnegieRochester Conference Serles on Publlc Pollcy 24 (Spring 1986), 55-103.

Ohlin, Bertel, "The German Transfer Problem: A Discussion," Economic Journal 39 (1929), 172-182.

Persson, Torsten and Lars Svenson, "Exchange Rate Varlability and Asset Trade," Rochester Center for Economic Research Working Paper No. 109 (November 1987)

Romer, Paul. "Capital Accumulation in the Theory of Long Run Growth," forthcoming in Robert Barro (ed.), Modern Business Cycle Theory (Cambridge: Harvard University Press), 1989.

Samolyk, Katherine, "Spatially-Separated Banking Markets and Asset Swaps," in Essays on Credit Flows and Macroeconomic Behavior, University of Wisconsin Ph.D. Dissertation (1988).

Stulz, Rene, "Cap1tal Mob1lity in the World Economy: Theory and Measurement: A Comment," In Karl Brunner and Allan H. Meltzer (eds.), CarnegleRochester Conference Serles on Public Polley 24 (Spring 1986), 105-113.

Tesar, Linda, "Saving, Investment and International Capltal Flows," Rochester Center for Economic Research Working Paper No. 174 (August 1988). 